\title{
Public Choice Lessons from the Wizarding World of Harry Potter
}

\section{Marta Podemska-Mikluch}

Gustavus Adolphus College

\section{Darwyyn Deyo}

George Mason University

\section{David T. Mitchell}

University of Central Arkansas

\begin{abstract}
J. K. Rowling's series of books about the underage wizard Harry Potter is an effective tool for introducing students to the key concepts of public choice. By keeping political figures at the forefront of the story, Rowling encourages students to recognize the different incentives individuals face in markets versus politics. To illuminate the pedagogical potential of the series and to ease its adoption, we discuss a set of examples that best illustrate the key concepts of public choice. We also share a classroom exercise showcasing how the series can be used to promote active learning.
\end{abstract}

JEL Codes: A11, A13, A22, D01, D7, D72

Keywords: edutainment, economic pedagogy, J. K. Rowling, Harry Potter, public choice, rent seeking

\section{Introduction}

The Harry Potter series is an abundant resource for any instructor interested in teaching public choice to undergrads. ${ }^{1}$ In addition to the incredible popularity of the series, ${ }^{2}$ there are two other reasons for

\footnotetext{
${ }^{1}$ Deyo and Podemska-Mikluch (2014) demonstrate the benefits of inviting Harry Potter and his friends into principles of economics classrooms. We build upon that work by illustrating the usefulness of the series in teaching public choice.

2 Of 1,000 individuals interviewed in 2006 for The Kids and Family Reading Report, 54 percent of children and 50 percent of adults had read at least one of the Harry Potter books (Yankelovich 2006). Interviewees were selected in a mall-intercept in
} 
using it to teach public choice. First, by keeping politicians and bureaucrats at the forefront of the story, Rowling helps students think about political incentives and focuses the class discussion on individual decision makers. Second, using fictional characters centers the discussion on the political mechanism, keeping it free from partisan digressions.

Even though the tradition of chalk and talk remains strong in economics (Watts and Becker 2008), economists have made significant contributions to the development of edutainment-a form of pedagogy that aims to educate through entertainment. For example, Dixit (2005) demonstrates how to use a mixture of multimedia resources to engage students in a game theory course. Others suggest using various collections of TV and movie clips to illustrate basic economic concepts (Leet and Houser 2003; Mateer 2004; Mateer, Ghent, and Stone 2011). Some focus on individual shows, such as The Simpsons (Hall 2005; Gillis and Hall 2010; Luccasen and Thomas 2010; Hall 2014), Seinfeld (Dixit 2012; Ghent, Grant, and Lesica 2011), or, most recently, South Park (Hoffer and Crowley 2015). Others recommend using such atypical tools as podcasts, comic strips, or even music (Lawson 2006; Lawson, Hall, and Mateer 2008; Van Horn and Van Horn 2013; Luther 2015).

The edutainment literature has focused primarily on supplying examples, or short stories, for instructors to use while introducing new material. Storytelling has been recognized as a great tool for helping students connect the new material to what they already know, and examples from popular culture are a great source of stories (Salemi 2002; Barkley 2009; Heath and Heath 2007; Gottschall 2012; Brown and McDaniel 2014). For this reason, we devote most of the paper to cataloguing examples that illustrate the key concepts of public choice. We focus on three key lessons: incentives in markets vs. politics, rent seeking, and rules vs. discretion. We also suggest a classroom activity that helps students absorb these ideas.

\section{Self-Interest vs. Social Interest in Markets and Politics}

In most economic formulations, the state is presented as having "an existence, a value pattern, and a motivation independent of those of the individual human beings claiming membership" (Buchanan and Tullock 1962). This organic vision, where the state is charged with

twenty-five major cities across the United States. It is likely that the number is significantly higher among children who later end up going to college. 
maximizing the social welfare function, is at the core of the public interest theory approach to government (Samuelson 1954, 1955). This approach closely overlaps with the approach most students bring into the classroom, as evidenced by students' frequent references to what the government should and should not do. However, to understand public choice, students need to discover that government is not an acting entity, but rather that governmental outcomes are generated through interactions among many individuals. Students also need to learn that political actors are not significantly different from market actors. Rather, what is different are the incentives embedded in markets versus politics.

While Adam Smith's (1776) famous words explain how the market mechanism aligns the butcher's self-interest with the interests of other market participants, students will quickly realize that in politics, personal and social interests are not as easily aligned. The wizarding world of Harry Potter is of great help in conveying this point, because it is inhabited by a remarkable number of political characters that are not significantly different from other wizards and Muggles (nonmagical folks). In fact, ethical and ethically dubious characters are as easily found among the wizarding politicians and bureaucrats as among those in other trades and professions.

A key public figure portrayed in the series is Cornelius Fudgethe head of the Ministry of Magic, which was established to keep the wizarding world secret from Muggles. We first meet the Minister for Magic when he arrives at Hogwarts to deal with a series of attacks on Muggle-born witches and wizards, in the early weeks of Harry's second year (Rowling 1999a, chap. 14). From the perspective of the public interest theory of government, the ministry should investigate every single crime until the culprit is found or until the marginal social benefit of investigation is greater than its marginal social cost. Yet, doing so is not conducive to the career advancement of the key decision makers. ${ }^{3}$ So even though the suspect of the attacks is unknown, Fudge decides to send Rubeus Hagrid—a half-giant gamekeeper-to prison:

"Look at it from my point of view," said Fudge, fidgeting with his bowler. "I'm under a lot of pressure. Got to be seen to be doing something. If it turns out it wasn't Hagrid, he'll

3 For the exploration of bureaucratic incentives for career advancement, see Tullock (1965). 
be back and no more said. But I've got to take him. Got to.

Wouldn't be doing my duty —" (Rowling 1999a, chap. 14). ${ }^{4}$

This scene can be used to open a number of classroom discussions: for example, a rational choice analysis of Fudge's decision. If asked about the benefits and costs of Fudge's choice, students will quickly notice that the benefits of arresting Hagrid are greater than the costs. The minister gets credit for resolving the mysterious attacks and boosts public image by appearing as a proactive public servant. Of course, as with any other choice, arresting Hagrid also comes with a cost: a risk of public opinion backlash once it becomes clear that an innocent man was arrested. But that risk is too small to outweigh the benefits: Fudge realizes that Hagrid's half-breed status means few will pay attention to Fudge's mistake. Students are sure to notice that it is Hagrid's vulnerability in the public eye that makes him an excellent suspect. ${ }^{5}$

While Fudge's behavior may seem possible only in a highly corrupt government, similar dynamics are not uncommon in modern democracies. Researchers have documented that when under pressure to resolve a case, police frequently end up focusing the investigation on a suspect with a low socioeconomic status. This is not necessarily because of a bias, but because among the suspects, this demographic is least likely to mount a strong defense or to arouse public support (Garrett 2011). Once there is a suspect, the investigation changes from investigating the crime to finding the evidence. As suggested by the growing number of wrongful convictions revealed through DNA testing, errors of commission happen more frequently than many are willing to admit when there is pressure to resolve a case.

\footnotetext{
${ }^{4}$ For the clip illustrating Hagrid being arrested, see the scene "Cornelius Fudge" at 1:50:39 of the film adaptation Harry Potter and the Chamber of Secrets.

5 Similar cost-benefit analysis explains Fudge's behavior when, during Harry's fourth year, Barty Crouch—a ministry official—disappears during a visit at Hogwarts and is later found dead. Fudge's first instinct is to cover up the scandal and to close the case. He suggests that Madame Maxime, a half-breed and a headmistress of a fellow wizarding school, killed Crouch. His claim is based on nothing more than the fact that Crouch's body was found close to Maxime's carriage. Madame Maxime is a half-Giant and a foreigner, so Fudge might assume that it would not be too hard to convince the public that she is to be blamed. This allegation is clearly untrue, and by making it, Fudge once again shows that his primary motivation is maintaining public image, not investigating and resolving the crime.
} 
Also to preserve his position and image, Fudge refuses to accept that the lethal Dark Wizard Voldemort regained strength after thirteen years of docility. Harry Potter and Dumbledore bring the news of Voldemort's return to Fudge (Rowling 2000, chap. 36). Even though they present significant evidence for Voldemort's return, Fudge refuses to believe them. Why? Given the high probability of Voldemort's return, shouldn't Fudge start preparing for a confrontation? From the perspective of public interest theory, the Minister should do all in his power to protect the citizens. But from Fudge's perspective, denying Voldemort's return is the strictly dominant strategy. If Fudge were to acknowledge Voldemort's return, he would need to take immediate steps: convince other members of the ministry that Voldemort is back, prepare, and lead a military confrontation. Given how lethal the Dark Wizard is known to be, preparing to face him openly means a very high probability of death. Also, acknowledging Voldemort's return means that if Potter and Dumbledore are wrong, Fudge will look paranoid and ruin his public image. So denial is preferred whether Voldemort is back or not. If Voldemort is back but Fudge denies it, Fudge is free to act as if nothing happened. The risk of being killed by Voldemort is also lower because Fudge is not preparing for a confrontation. And there is also a slight chance of the best case scenario: Potter and Dumbledore are wrong, and Fudge makes the right decision to ignore them.

\section{Rent Seeking}

No public choice course would be complete without a discussion of rent seeking - an effort to increase one's share of wealth without creating new wealth, usually by getting a regulation in place that hampers competitors or by obtaining an implicit or explicit subsidy. In the wizarding world of Harry Potter, rent seeking takes a variety of forms. It is clear that minister Cornelius Fudge is in the pocket of Lucius Malfoy, a head of the prominent wizarding family. There are many hints at this connection throughout the series, but the confirmation comes during Harry's trial for using magic outside of Hogwarts. At that time, Lucius Malfoy is seen talking with Fudge about his next "donation."

"What are you doing here anyway?" Harry asked Lucius Malfoy. "I don't think private affairs between myself and the Minister are any concern of yours, Potter," said Malfoy, smoothing the front of his robes; Harry distinctly heard the 
gentle clinking of what sounded like a full pocket of gold. "Really, just because you are Dumbledore's favorite boy, you must not expect the same indulgence from the rest of us ... Shall we go up to your office, then, Minister?" "Certainly," said Fudge, turning his back on Harry and Mr. Weasley. (Rowling 2003, chap. 9)

We then learn from Mr. Weasley that Lucius Malfoy gives "generously to all sorts of things," and that this generosity allows him to ask favors: for example, to delay laws he finds unfavorable.

Similar to Fudge, other ministry officials are also open to granting favors. Dolores Umbridge-Senior Undersecretary to the Minister for Magic-exempts from inquisition into their "blood status" favored members of the ministry while less popular (and less privileged) witches and wizards are threatened with losing their wands and even being sent to Azkaban on spurious or false charges. She even takes a bribe from a smuggler, Mundungus Fletcher, when she catches him operating without a license (Rowling 2007, chap. 11). This favoritism and arbitrariness reflect the impact of lobbying on the passage and nature of adopted regulations. It also illustrates the entanglement between private and public agents—very different from the vision of politics as separate from markets. ${ }^{6}$

In addition to illustrating the interactions between private and public actors, Rowling also offers an example of the government's regulatory intervention in markets. After graduating from Hogwarts, Percy Weasley takes a clerical job in the Department of International Magical Cooperation, and in the summer before Harry's fourth year at Hogwarts, Percy is deep in research on foreign-made cauldrons. He says there is an influx of "thin-bottomed cauldrons," an issue that he considers to be of paramount importance.

"What are you working on?" said Harry. "A report for the Department of International Magical Cooperation," said Percy smugly. "We're trying to standardize cauldron thickness. Some of these foreign imports are just a shade too thin-leakages have been increasing at a rate of almost three percent a year ... Unless some sort of international law is imposed we might well find the market flooded with flimsy, shallow-bottomed products that seriously endanger-" (Rowling 2000, chap. 5)

\footnotetext{
${ }^{6}$ For an elucidation of this idea, see the literature on entangled political economy (Wagner 2007; Podemska-Mikluch and Wagner 2010; Smith, Wagner, and Yandle 2011).
} 
This scene provides a clear example of protecting domestic industries from foreign competition and offers a great introduction to a discussion on who should be responsible for the safety of products sold in the market. It can also be used to start a discussion on the costs and benefits of regulation.

\section{Rules vs. Discretion}

While clearly not a fan of politics, Rowling is not an anarchocapitalist. Rather, she is a strong advocate for rules over discretion. Her approach is similar to that of Hayek, Buchanan, and other classical liberal thinkers (see, e.g., Hayek 1960, 1973; Buchanan and Tullock 1962; Brennan and Buchanan 1985; Buchanan and Congleton 1998; Stringham 2015). Rowling's preference for rules is clear: at Hogwarts-under Dumbledore's leadership_rules are clearly defined and uniformly applied. There is no discretion, no arbitrariness, no room for interpretation. Harry, Hermione, and Ron know exactly when they are following the rules and when they are breaking them. They also know what punishment to expect for breaking the rules. In contrast, wizarding politicians and bureaucrats display a much more flexible approach to rules, applying them as they see fit for whatever goals they are pursuing.

The purely arbitrary application of rules is illustrated, and condemned, by how the Ministry of Magic enforces the Decree for the Reasonable Restriction of Underage Sorcery. The decree forbids the use of underage magic outside of school with the intention to protect the secrecy of the magical world. Even though any spell conjured outside of Hogwarts by a wizard or witch under seventeen years of age is considered underage magic, traditionally the ministry focused only on administering warnings and punishments for spells conjured in the presence of Muggles. Since the ministry can detect where the spell is cast but not by whom, Harry receives a warning letter from the ministry for conjuring a Hover Charm that, in fact, was cast by Dobby, a house elf. The warning letter contains a reminder that underage wizards are not supposed to use magic outside of Hogwarts (Rowling 1999a, chap. 2). This written reminder is portrayed as a standard procedure in case of underage use of magic. A year later, when Harry accidentally inflates Aunt Marge, he fears that this second act of underage wizardry will get him expelled from Hogwarts. Yet, to Harry's surprise, no action is taken. The ministry is busy dealing with the escape of Sirius Black from Azkaban, and the Minister wants to secure Harry's support (Rowling 
1999b, chaps. 2-3). Finally, in the summer before his fifth year, Harry uses the Patronus Charm to ward off the Dementors. Even though Harry uses magic in self-defense, he comes close to being expelled from Hogwarts, as now he and Dumbledore are considered to be the enemies of the state (Rowling 2003, chaps. 1, 8).

\section{Classroom Experience}

There are many ways to incorporate the Harry Potter series in a public choice course. The presented examples are just a small selection of what the books have to offer. Instructors who want to use stories to help students connect with new material will find that the series is an abundant source of examples and can be incorporated in a variety of creative ways. Playing clips while introducing new concepts is among the most popular methods. Dirk Mateer has long been a proponent of this approach, and his work provides a multitude of examples for use across the economics curriculum (Mateer 2004; Mateer, Ghent, and Stone 2011; Hunt Ferrarini and Mateer 2014). He also provides illustrations specific to a public choice course (Mateer and Stephenson 2011). Diamond (2009), focusing on creative destruction, also suggests playing clips as a way of introducing stories to reinforce understanding and memorization.

Inspired by the edutainment literature, we also played various clips in our classrooms in the past. This time, however, we have taken this idea a step further. In the effort to promote active learning, we designed an assignment oriented at inducing student engagement. Instead of using the clips to illustrate the concepts, we used them to summarize and review the material. At the beginning of class, students were given a worksheet with a list of seven clips that we subsequently played for them. The worksheet came with instructions asking students to write down what public choice ideas and concepts they recognized in each clip. We also asked the students to consider how the concepts in the movies relate to the real world. Each clip was less than two minutes long, leaving enough time for students to write down their answers and have a short discussion after each clip.

We began this exercise with the scene where Dolores Umbridge threatens to use an illegal curse on Harry. Students' responses were relatively broad and included security versus freedom, bureaucracy, mob mentality, fear mongering, rational ignorance, and rational irrationality. These answers created a launching pad for a discussion and opportunity for additional clarification. At the end of the 
exercise, we asked that students share their own examples that they thought pertained to public choice.

There were twenty-three students in the section, but only nine responded to the anonymous end of the year student course evaluations. The evaluations did not ask about the Harry Potter exercise, but three of the nine students brought it up in their responses:

- "The Harry Potter day near the end of the semester was great. I hope it helps on the final, but it was so fun that the economics club should do it."

- "Now whenever I watch TV or movies I think about economics."

- "This [Harry Potter exercise] helped me to remember and assimilate easily the different concepts encountered in the class."

These comments suggest that the exercise was a success. We attribute this result to its engaging and entertaining nature. We share the worksheet along with the description of each clip in the appendix to make it easier for other instructors to replicate this exercise in their classrooms.

\section{Conclusions}

Following the work of Deyo and Podemska-Mikluch (2014), we have argued that the Harry Potter series is not only a great resource for introductory courses but can also be successfully used to teach public choice. We sought to illustrate the abundance of appropriate examples that suggest great pedagogical benefits of incorporating the series into the classroom. We believe that students will benefit from these examples even more if asked to figure out what public choice ideas and concepts are illustrated in each clip.

James Buchanan (2005) observed that "ceding control over their actions to others allows individuals to escape, evade, and even deny personal responsibilities." This tendency generates a world of "perpetual childhood" where individuals are free "from all the troubles of thinking and all the cares of living," leading to democratic despotism, a risk captured by Tocqueville in his prominent Democracy in America (1838). To stop this trend, educators committed to the ideas of liberty must relentlessly communicate the burden that comes with ceding control. This is not an easy task. To be discouraged from ceding control, students must adopt the economic way of thinking and learn to use it to understand the political process. We argue that 
using examples from the bestselling series of books about the underage wizard Harry Potter is an effective way of getting students to understand that policy is not chosen by a benevolent dictator but rather is generated through interactions among individuals in the pursuit of their diverse and often conflicting plans.

\section{References}

Barkley, Elizabeth F. 2009. Student Engagement Techniques: A Handbook for College Faculty. San Francisco: Jossey-Bass.

Brennan, Geoffrey, and James M. Buchanan. 1985. The Reason of Rules: Constitutional Political Economy. Indianapolis: Liberty Fund.

Brown, Peter C., and Mark A. McDaniel. 2014. Make It Stick: The Science of Successful Learning. Cambridge, MA: Belknap.

Buchanan, James M. 2005. “Afraid to Be Free: Dependency as Desideratum.” In Policy Challenges and Political Responses, edited by William F. Shughart II and Robert D. Tollison, 19-31. Springer.

Buchanan, James M., and Gordon Tullock. 1962. The Calculus of Consent: Logical Foundations of Constitutional Democracy. Ann Arbor, MI: University of Michigan Press.

Buchanan, James M., and Roger D. Congleton. 1998. Politics by Principle, Not Interest: Towards Nondiscriminatory Democracy. Cambridge, UK: Cambridge University Press.

Deyo, Darwyyn, and Marta Podemska-Mikluch. 2014. "It's Just Like Magic: The Economics of Harry Potter." Journal of Economics and Finance Education, 13(2): 90-98.

Diamond, Arthur M. 2009. "Using Video Clips to Teach Creative Destruction." Journal of Private Enterprise, 25(1): 151-61.

Dixit, Avinash. 2005. "Restoring Fun to Game Theory." Journal of Economic Education, 36(3): 205-19.

Dixit, Avinash. 2012. "An Option Value Problem from Seinfeld." Economic Inquiry, 50(2): 563-65.

Garrett, Brandon L. 2011. Convicting the Innocent: Where Criminal Prosecutions Go Wrong. Cambridge, MA: Harvard University Press.

Ghent, Linda S., Alan Grant, and George Lesica. 2011. "The Economics of Seinfeld.” Journal of Economic Education, 42(3): 317-18.

Gillis, Mark T., and Joshua Hall. 2010. "Using the Simpsons to Improve Economic Instruction through Policy Analysis." American Economist, 55(1): 84.

Gottschall, Jonathan. 2012. The Storytelling Animal: How Stories Make Us Human. New York: Houghton Mifflin Harcourt.

Hall, Joshua. 2005. "Homer Economicus: Using the Simpsons to Teach Economics." Journal of Private Enterprise, 20(2): 165-76.

Hall, Joshua, ed. 2014. Homer Economicus: The Simpsons and Economics. Stanford, CA: Stanford Economics and Finance.

Hayek, Friedrich A. 1960. Constitution of Liberty. Chicago: University of Chicago Press. 
Hayek, Friedrich A. 1973. Law, Legislation and Liberty: A New Statement of the Liberal Principles of Justice and Political Economy. Chicago: University of Chicago Press.

Heath, Chip, and Dan Heath. 2007. Made to Stick: Why Some Ideas Survive and Others Die. New York: Random House.

Hoffer, Adam J., and George R. Crowley. 2015. "Did You Say That Voting Is Ridiculous? Using South Park to Teach Public Choice." Journal of Private Enterprise, 30(3): 103-09.

Hunt Ferrarini, Tawni, and Dirk G. Mateer. 2014. "Multimedia Technology for the Next Generation.” Journal of Private Enterprise, 29(2): 129-39.

Lawson, Robert A. 2006. "Teaching Economic Principles with Comic Strips." Journal of Private Enterprise, 22(1): 168.

Lawson, Robert A., Joshua Hall, and G. Dirk Mateer. 2008. "From Abba to Zeppelin, Led: Using Music to Teach Economics." Journal of Economic Education, 39(1).

Leet, Don, and Scott Houser. 2003. "Economics Goes to Hollywood: Using Classic Films and Documentaries to Create an Undergraduate Economics Course.” Journal of Economic Education, 34(4): 326-32.

Luccasen, R. Andrew, and M. Kathleen Thomas. 2010. "Simpsonomics: Teaching Economics Using Episodes of The Simpsons." Journal of Economic Education, 41(2): 136-49.

Luther, William J. 2015. "Using NPR's Planet Money Podcast in Principles of Macroeconomics." Journal of Private

Enterprise, 30(1): 143-54.

Mateer, G. Dirk, and E. Frank Stephenson. 2011. "Using Film Clips to Teach Public Choice Economics." Journal of Economics and Finance Education, 10: 28-36.

Mateer, G. Dirk. 2004. Economics in the Movies. South-Western College Pub.

Mateer, G. Dirk, Linda S. Ghent, and Misty Stone. 2011. "TV for Economics." Journal of Economic Education, 42(2).

Podemska-Mikluch, Marta, and Richard E. Wagner. 2010. "Entangled Political Economy and the Two Faces of Entrepreneurship." Journal of Public Finance and Public Choice, 27(2-3): 3-18.

Rowling, J. K. 1999a. Harry Potter and the Chamber of Secrets. New York: Scholastic.

Rowling, J. K. 1999b. Harry Potter and the Prisoner of Aqkaban. New York: Scholastic.

Rowling, J. K. 2000. Harry Potter and the Goblet of Fire. New York: Scholastic.

Rowling, J. K. 2003. Harry Potter and the Order of the Phoenix. New York: Scholastic.

Rowling, J. K. 2007. Harry Potter and the Deathly Hallows. New York: Scholastic.

Salemi, Michael K. 2002. "An Illustrated Case for Active Learning." Southern Economic Journal, 721-31.

Samuelson, Paul A. 1954. "The Pure Theory of Public Expenditure." Revien of Economics and Statistics, 387-89.

Samuelson, Paul A. 1955. "Diagrammatic Exposition of a Theory of Public Expenditure." Review of Economics and Statistics, 37(4): 350.

Smith, Adam. 1776. An Inquiry Into the Nature and Causes of the Wealth of Nations. London: W. Strahan and T. Cadell.

Smith, Adam, Richard E. Wagner, and Bruce Yandle. 2011. "A Theory of Entangled Political Economy, with Application to TARP and NRA." Public Choice, 148(1-2): 45-66. 
Stringham, Edward Peter. 2015. Private Governance: Creating Order in Economic and Social Life. Oxford, UK: Oxford University Press.

Tocqueville, Alexis de. 1838. Democracy in America. New York: G. Dearborn \& Co.

Tullock, Gordon. 1965. The Politics of Bureaucracy. Washington, DC: Public Affairs Press.

Van Horn, Robert, and Monica Van Horn. 2013. "What Would Adam Smith Have on His iPod? Uses of Music in Teaching the History of Economic Thought." Journal of Economic Education, 44(1): 64-73.

Wagner, Richard E. 2007. Fiscal Sociology and the Theory of Public Finance: An Exploratory Essay. Cheltenham, UK and Northampton, MA: Edward Elgar.

Watts, Michael, and William E. Becker. 2008. "A Little More than Chalk and Talk: Results from a Third National Survey of Teaching Methods in Undergraduate Economics Courses." Journal of Economic Education, 39(3): 273-86.

Yankelovich, Daniel. 2006. "Kids and Family Reading Report." New York, NY: Scholastic.

Appendix: Instructor's Manual for the Classroom Activity: Public Choice Lessons from the Wizarding World of Harry Potter

Start the class by handing out a worksheet with a list of clips that you will subsequently play for the students. In this particular assignment, all the scenes come from Harry Potter and the order of the Phoenix. We provide the location of each scene within the movie in the brackets. While you can assign grades or use treats to reward particularly good answers, in our case there was no need for extrinsic rewards because the students were eager to participate.

The Hearing (20:49): Dumbledore argues with Minister for Magic during Harry's disciplinary hearing regarding the use of underage magic. The scene is particularly interesting because of Fudge's "Laws can be changed!" retort. Real world parallels include the importance of constitutions and the risk of constitutional erosion.

Detention with Dolores (37:40): As Harry shows up for his detention, Umbridge asks him to use the special quill to write lines. When Harry writes, "I must not tell lies," the same words cut into his hand. Real world parallels include abuse of authority, mandatory minimum sentencing, and discretion among political figures.

The Hogwarts High Inquisitor (45:00): Umbridge seeks to establish the Ministry's control over Hogwarts. In her pursuit of control, she establishes a litany of new rules and prohibitions. Real world parallels include political entrepreneurship and government growth.

Firing of Professor Trelawney (48:35): Umbridge culminates her usurpation of control at Hogwarts with the firing of professor 
Trelawney. Real world parallels include the role of government in education.

Umbridge's illegal curse (1:39:23): In the attempt to communicate with his godfather, Harry and his friends break into Umbridge's office. When Umbridge catches them, she threatens to use an illegal curse on Harry to get him to confess why he was there. Real world parallels include the use of torture in the name of national security and laws applying differently to politicians and bureaucrats than to civilians.

\section{Classroom Activity: Public Choice Lessons from the Wizarding World of Harry Potter}

In this activity, we analyze the world of politics from the public choice perspective. But we're looking not at the real world, but at the wizarding world of Harry Potter. You will watch a series of clips presenting at least one topic or model that we discussed in class. After watching each clip, write down what topics or models the clip illustrates and at least one real world parallel. We will discuss your observations after watching all the clips.

1. The Hearing

2. Detention with Dolores

3. The Hogwarts High Inquisitor

4. Firing of Professor Trelawney

5. Umbridge's Illegal Curse

Suggest your own clips from the Harry Potter series that would be relevant to this class. Which topics do they illustrate? Which clips from other movies or television would be appropriate? 